\title{
ANALYSIS OF MONITORING ROLE OF SCHOOL COUNCILS IN GOVERNMENT SECONDARY SCHOOLS OF PUNJAB
}

\author{
Ziarab Mahmood \\ Assistant Professor, Department of Education, \\ MIU University Nerian Sharif, \\ AJ\&K, Pakistan \\ Email: ziarabmahmood@gmail.com \\ Makhdoom Ali Syed \\ Professor, Dept. of Education, \\ University of Kotli, \\ AJ\&K, Pakistan \\ Email: makhdoomalisyed@yahoo.com

\section{Javed Iqbal} \\ Assistant Professor, Department of Education, \\ Hazara University Mansehra, \\ Punjab, Pakistan \\ Email: javediqbal173@hu.edu.pk
}

\begin{abstract}
The purpose of this research was to analyze the monitoring role of school councils in secondary schools of Punjab in term of monitoring of students and teachers' attendance, and collection and consumption of funds. The data were collected from 100 school councils (3 members from each) ensuring 50:50 respondents from urban and rural; male and female schools through semi structured interview consisting of ten items. The recorded interviews were analyzed with the help of two experts. It was found that school councils were not playing any significant role in term of monitoring of students and teachers' attendance. It is recommended that school councils may be strengthen and training may be given to the members of the executive body of the schools councils about their duties so that they may be aware of their duties and responsibilities and may be able to perform their duties efficiently.
\end{abstract}

\section{KEYWORDS}

Monitoring, school council, teacher attendance, Punjab 


\section{INTRODUCTION}

Community participation in education is common practice in world. Concept of Community participations in education appears in Chicago in 1987 when first meeting was held in Marietta high school. It was given name of Parents Teachers Association (PTA) a non-profit organization (Wikipeadia, 2019). Due to its effectiveness in promoting quality of education, the other countries of the world also adopted it in schools, colleges, hospitals and other state department as parents' involvement advisory committee (PIAC) in Toronto, Canada (Karim, 2020).

Community participation and community empowerment in education have great impact on education (Govinda and Diwan, 2005). Educational targets cannot be met without the active participation of the society. Hence it is needed to empower the communities' members and established the legal bodies consisting on parents, communities' members, intellectuals and school staff in the education set up of the schools (Sajjad, 2006).

Pakistan is a federal state with four provinces, capital, federal administrative tribal areas, federal administrative northern areas, and state of Azad Jammu and Kashmir; and education is a provincial matter hence different bodies of communities' involvement were formed with different names and functions. Parents Teachers Associations in Islamabad, School Management Councils and School Councils in Punjab, Parents Teachers Associations in Sind, Parents Teacher School Management Committees (PTSMC) in Baluchistan, Parents Teachers Association (PTAs) in KPK were constituted. In 1993-94, social action program was launched in Pakistan to provide the basic need to the masses of Pakistan. As education is also considered the fundamental right of every Pakistani, hence education was also included in social action program. To gain the result, it was decided to involve the parents and the society in education in 1994. Thus school management committees consisted on 12 members and school repair committees were constituted in schools of Punjab wide letter No. SO (CORR) CMS-OT-4/95 dated 26-4-95. These committees remained ineffective due to some reasons and these were reconstituted in 1998 with minor changes as the members were reduced from 12 to 9 as it was decided in new educational policy 1998-210 (Government of Pakistan, 1998).

These committees also remained ineffective because no power was given to them like keeping account, maintain record of meetings etc. In 2000, again these committees were reconstituted and renamed as school councils. These school councils were reframed and it was decided that a school council must have 11 members consisting of parents of the students enrolled in that school, a lamberdar, a student (in middle and high school), two retired government servants and teachers. Beside this, other prominent member may also be included. 
In 2003, again minor changes were made in these school councils. It was decided to ensure $50 \%$ participation of parents, and a parent will be the head of school council. Beside this, these councils were authorized to expend up to 400000 rupees on school program (Government of Punjab, 2020). Now the member of school council can be minimum 7 and maximum 15 . Head of the school is chairman of school council (Habib, 2010).

In 2001, the decentralization of educational management took place under the program of devolution of power. Education management was decentralized at district level in Punjab. In the largest province of Punjab, school management committees were established in 1994. These committees could not produce fruitful result hence these were redesigned and renamed as school councils in 2007. The structure of school councils changed from time to time. Now it is essential that school council must consist of seven members and it can be maximum fifteen members in a school. There is three nominated members a teacher, a local influential person, a social worker and three elected parents. Head teacher of school is chairman of the school (Habib, 2010). The major purposes of school councils were to monitor teachers' attendance, to increase students' enrolment by motivating parents, to build the consciousness of the parents about the importance of education, to mobilize the community to help the schools' management by providing missing facilities and to monitor the implementation of schools program (Habib, 2010; Shah, 2009).

School councils can be fruitful in number of ways like planning, monitoring, fund generating campaign, improving the quantity as well as quality of education etc. It is decided to hold meeting of school council once in a two month. It is expected that school councils will maintain the record of meetings on prescribed Performa.

\section{LITERATURE REVIEW Monitoring}

Monitoring is watching the implementation of program. It is continuous and may be part of administration or independent from the department. But it is an essential tool of evaluation; and evaluation is part of management. Therefore, monitoring is said integral part of management or administration. Administration cannot achieve its objectives without efficient and affective system of monitoring. So, affective monitoring system is requirement of every organization, institution, and administration. Administration of educational institutions works to achieve some objective, to meet some targets and to fulfill some standards so these institutions have need of monitoring.

\section{Education monitoring}

Education monitoring works to watch the implementation of education program 
vigilantly and continually. In our country Pakistan, at schools level, education monitoring involves watching the attendance of teachers, enrollment of students, distribution of books, collection of funds, utilization of funds, educational facilities (drinking water, boundary wall, classrooms, playground etc.), non-teaching staff, teaching learning process, and school councils etc. besides this, some programs are launched for some period like No Child Left Behind, Zero dropout, and $100 \%$ enrollment and monitoring these program is also part of educational monitoring at school level.

\section{Types of Education Monitoring}

Basically there are two types of monitoring; within department monitoring which is also called departmental or independent monitoring and out of department monitoring which is called independent, external or third party monitoring. In schools of PunjabPakistan, both these monitoring systems work side by side. School education department is responsible to monitor the educational program. For this purpose duties are assigned to education officers (Government of Punjab, 2020b) . To cross check the implementation of educational program, multiple independent monitoring systems were developed in Punjab. Among these systems, Chief Minister monitoring Force is the top monitoring system which directly works under the supervision of Chief Minister of the Punjab. Program Monitoring and Implementation Unit was also established in Lahore which works with the help of District Monitoring Officers (DMO), and Monitoring and Evaluation Assistant who collects data, feed it in monitoring electronic device and send it to DMO in this way within no time data reached in DMO and PMIU head quarter (Government of Punjab, 2020a). Beside this School Management Committees/ school councils are also responsible to monitor the education Program as a third party monitoring system.

\section{School Councils}

Concept of community participation is education is very old. Today school councils are part of almost every school in public sector of the world. School councils were given different names like school management committees, parents' councils, parents' teacher councils and schools councils etc. the purpose of such councils remain to involve the community in decision making of schools administration and help and work for school improvement. This concept appears in Pakistan in 1994. Now, school councils are part of every public sector school of Punjab (Islam, 2017).

\section{RESEARCH OBJECTIVES}

The purpose of this research was to study the school councils and analyze the monitoring role of school councils in secondary schools of Punjab. Lack of accountability is the main cause of low productivity/performance in department of education like other departments. To monitor the quality of education, teachers and 
students attendance and collection and consumptions, Schools Councils were formed. So it was needed to analyze this specific role of school councils. It will provide the correct and grounded realities of school councils in perspectives of monitoring performance of school councils to make future decision.

\section{RESEARCH QUESTIONS}

1. What is role of school councils in monitoring quality of education in secondary schools of Punjab?

2. What is the role of School councils in monitoring the attendance of students and teachers?

3. What is the role of school councils in monitoring the collection and consumption of funds?

\section{RESEARCH METHODOLOGY}

It was qualitative research. Literature was reviewed to know the history and efforts of school councils in Punjab. To find the monitoring role of school councils a semi structured interview was conducted. Recorded interview was analyzed with the opinions of panel of experts. All the school councils of secondary schools of Punjab comprise the population of the study. Following multistage sampling technique was applied to take appropriate sample:

In first stage, Rawalpindi division was selected randomly. In second stage, one hundred school councils of secondary schools were selected randomly from four districts of Rawalpindi Division (Rawalpindi, Attock, Jehlm and Chakwal) ensuring 50:50 school councils of urban and rural, male and female schools. In third stage, three members of each selected school councils were selected purposively as respondents of the study. To take appropriate response, a teacher member, a parent member and chairman of the school council were taken in sample. Semi structured interview technique was applied to collect the data. Face to face interview was conducted so the response rate was cent per cent. During interview, main points were written or recorded. Similarities and differences of the responses were judged with the help of panel of two experts. On the base of experts' opinions and maximum frequency of similar response, results were generalized.

\section{RESEARCH FINDINGS}

Mostly members of school councils have no knowledge of their responsibilities. Members of school councils told that neither they were given any booklet, brochure or informative material about their responsibilities nor they were given any training in this respect. The results were same in the school councils of Male and female, urban and rural areas. 
Majority of the respondents responded that school councils have played no role to monitor the students' attendance and retention rate. School councils also remained ineffective in sense of motivating parents to send their children in to schools. That is why, many children are not enrolled in any school and the targets of the government of Punjab, were not met yet. Some positive sign were found in respect of increasing the enrolment of the students in elementary schools but these results were not due to monitoring practice of school councils. Respondents told that enrolment has been increased due to motivation of head teachers and teachers as it is the policy of the government to reduce the teachers from those schools where students' enrolment is low. Hence to save the teaching posts in school, school teachers as well as head teachers have taken efforts to increase enrollment. These results were found same in school councils of boys and girls and urban and rural schools.

The results indicate that school councils do not monitor the attendance matter of the teachers. The school councils have zero input to stop the teacher absenteeism. Many teachers were found on casual leave, medical leave and study leaves. Late arrival of the teachers, were also found in the schools but school councils have no authority to stop these types of absenteeism. Teachers told that teachers reached late because of long distance from home to school and non-availability of transport. Head teachers told that some period of some classes were missed due to medical unfitness of teachers, late arrival of the teachers, shortage of teaching staff, and non-committed behavior of the teachers. It was also found that political involvement is also one of the reasons of teachers' absenteeism. In this respect, schools councils of urban area schools are slightly better than school councils of rural areas but still not effective to control.

In case of monitoring of the utilization of the funds, school councils of urban areas are effective up to some extent but still it is needed to strengthen. In rural areas school councils remained ineffective. In some schools, school councils monitor the collection and consumption of the funds but in most of the schools, concerned members of the school councils just signed on the registers on the request of the head teachers. No difference was found between male and female school councils.

\section{CONCLUSIONS \& DISCUSSIONS}

Overall results of the present study indicate that school councils have not played effective role to monitor the quality of education, students and teachers' attendance and utilization of the funds. It may be due to non-implementation of set criteria of formation of school councils as members of school councils must be selected through election in school in presence of senior officer. Non-availability of training of members and selection of irrelevant and illiterate person may also be the reason of this failure. Results of some other researches also support the results of present research as a study was conducted by Saeed (2008) "Effectiveness of School Council Scheme in 
Elementary Schools of Punjab in Improving the Standard of Education". He concluded that overall result of school councils in Chakwal district is positive but schools councils are not effective as it was expected. Comparatively in female schools, school councils are more effective than that of male schools. He concluded that member of school councils are not well qualified nor they were given training so they cannot show effective result.

Another research was conducted by Shah (2009) "Monitoring the quality of secondary education in context of decentralization in Pakistan". He concluded that supervisor are unable to monitor the schools due to burden of official work, absence of proper mechanism of monitoring and evaluation, non-availability of transport facilities, far furlong schools etc.

Nasira Habib conducted a research in 2010 on the topic "Understanding the Role of School Council" to find out the performance of school councils. She concluded that school councils have not achieved the goals for which these councils were formed. According to her, education bureaucracy is not committed to empower the school councils. Perhaps they considered it, extra check on them. To evaluate the school management committees in promoting education in Punjab, Sajjad (2006) has conducted a research. He found that SMCs members are in favour of the improvement of educational standard and management of school but SMCs have not succeeded to do so.

In the same way recently a research was conducted by Abdul Karim on the topic Evaluation of School Management Committees on the School Improvement at Elementary Level in AJ\&K. He concluded that performance of school management committee is not satisfactory regarding monitoring of attendance matter of students as well as teachers. The committees also have no role in increasing students' enrollment in AJ\&K (Kari, 2020). The results of above mentioned researches clearly support the results of this research. In short we can say that school management committees are playing any significant role in promotion of education in the Punjab as well as in other parts of Pakistan.

\section{RECOMMENDATIONS}

1. On the base of findings it is recommended that training may be given to the members of school councils. One week training may be arranged to aware them about their duties, authorities and responsibilities so that these school councils may be able to play effective role of monitoring as well as administrative. Job description may be finalized and printed material may be given to the members of school councils.

2. Performance of school councils may be appreciated in the shape of award certificate, cash prize and including their performance in the annual performance booklet/journal. 
3. School councils may be motivated and given incentives to motivate the people to send their children to schools. One member of school council may be assigned the duties to monitor the students and teachers' attendance.

4. Finance secretary of the school councils may be authorized to monitor the financial matters of the school.

5. Monitoring Performa for school councils may be developed and monthly filled Performa may be submitted to the office of the area education officer. Disciplinary action may be taken according to the monitoring reports of the school councils.

\section{REFERENCES}

Ahmad, S. (2008). Effectiveness of School Council Scheme in Elementry Schools of Punjab in Improving the Standard of Education. Unpublished Master Thesis. Islamabad: Allama Iqbal Open University.

Mumtaz, M. \& Awan, A.G. (2019). Exploring the Role of School Council in Promoting Elementary Education in Punjab-Pakistan. Global Journal of Management, Social Sciences and Humanities 5(2).

Government of Punjab. (2001). The Punjab Local Government Ordinance, 2001. Lahore: OPS WING, NRB.

Government of Pakistan. (2003). Quality of Primary Education. Islamabad: Ministry of Education.

Government of Punjab. (2020a). PMIU Program and Projects. Department of School Education. PERSP.www.persp.edu.pk/pmiu.php?v=programs\#8 dated 22/10/2020

Government of Punjab. (2020b). Head Teacher Guide for Primary and elementary Schools. Lahore: Directorate of Staff Development.

Govinda, R. Diwan, R. (2005). Community Participation and Empowerment in Primary Education. New Delhi 110017: b 42, Panchsheel Enclave, Sage Publications India Pvt. Ltd.

Habib, N. (2010). Understanding the Role of School Council. Lahore: KHOJ Society for People Education.

Islam, R. (2017). School Council Policy in Punjab: Policy Formulation o without Participation of Stakeholders. Journal of Education \& Social Sciences 5(2). DOI: 10.20547/ jess 0421705103

Karim, A. (2020). Evaluation of School Management Committees on the School Improvement at Elementary Levl in AJ\&K. Unpublished Master Thesis. AJ\&K: Department of Education, Mohi-ud-Din Islamic University Nerian Sharif.

Sajjad, M.L. (2006). Evaluation of School Management Committees in Promoting Education in Punjab. Unpublished Master Thesis. Islamabad: AIOU.

Shah, D. (2009). Monitoring the Quality of Secondary Education in the Context of Decentralization in Pakistan. Lahore: Bulliten of Education \& Research (ISSN 05557747) Volume 31 no 1, IER, University of the Punjab. 